\title{
The Development Fortified Pan Bread by Increasing Its Protein Content with High Levels of Live Yeast cells Saccharomyces Cerevisiae
}

\author{
Doaa A Sadek ${ }^{1}$, Omyma El-Sayid Shaltot ${ }^{2}$, Nader R Abdelsalam ${ }^{2 *}$, Mona Mohamad Sharf ${ }^{1}$ and Amro Abd El-Fatah \\ Amara $^{1}$
}

${ }^{1}$ GEBRI, Egypt

${ }^{2}$ Faculty of Agriculture (Saba-Basha) Alexandria University, Egypt

Received: 阱April 17, 2018; Published: 些眥 May 04, 2018

*Corresponding author: Nader R Abdelsalam, Faculty of Agriculture (Saba-Basha) Alexandria University, Egypt

\begin{abstract}
The main objective of the research is to develop pan bread nutritional value through fortification with high concentration of live yeast cells (Saccharomyces Cerevisiae). Fortified pan bread boosts the nutritional status of poor people and reduces the incidence of infertility diseases. The bread was reformulated by adding various concentrations of S. Cerevisiae at 5, 10, 15, 20 and 30g/ $\mathrm{kg}$ wheat flour. The bread was baked using the straight dough method. Protein, carbohydrate, moisture, fat, vitamin B complex, minerals, energy value, amino acids profile and Sensory evaluation were conducted on the fortified pan bread were evaluated. Results revealed that the carbohydrate, moisture, vitamin B complex, minerals, protein content and amino acids pattern increased with the increase in concentration of S. Cerevisiae. The sensory test showed that pan bread fortified with S. Cerevisiae concentration at $5,10,15 \& 20 \mathrm{~g} / \mathrm{kg}$ wheat flour were accepted by panelists, while pan bread at $30 \mathrm{~g} / \mathrm{kg}$ concentration was unacceptable. This study shows the potential of using high concentration of S. Cerevisiaein improving protein quality and nutritional value of pan bread consumed by economically disadvantaged communities.
\end{abstract}

Keywords: Bread; Fortification; Nutrition; Protein Amino Acids; Yeast; Saccharomyces Cerevisae; Carbohydrate; Vitamin Supplements; Nutritional Yeast; Biomass Production; Sensorial Quality

\section{Introduction}

Bread is the main product of wheat which is manufactured commercially. Eating grain foods, like bread consumed a lot by economically disadvantaged communities. it is plays an important role in the diet by providing many nutrients, such as carbohydrate, Protein, dietary fiber, vitamins and minerals, which are vital for the health and maintenance of the body Pareyt [1]. But wheat flour which is the basic ingredient in bread is lack crucial nutrients such as essential amino acid lysine and B complex vitamins Wardlaw [2]. One way of improving the nutritional quality of pan bread is fortification with bakery yeast Saccharomyces Cerevisiaeto enhancing bread protein content Friedman \& Finot [3]. Saccharomyces Cerevisiae has high nutritional value is rich in content of the proteins, vitamin B complexes and minerals such as calcium, phosphorus, manganese, magnesium, zinc and copper and has high biological value of essential and nonessential amino acids so it has several health benefits Shrinandan [4]. Saccharomyces Cerevisiae as a single cell protein is a rich source of proteins which are necessary for replacing worn out tissues or recovery after infections and contains 18 amino acids and is considered to be $55 \%$ high quality protein. It is a rich source of B vitamins which aid in lowering stress, help in metabolism, prevent cancer and ensure a healthy skin and it is low in fat and hence low in cholesterol content it maintains optimum cholesterol levels, improves blood production and also improves liver health and function Bekatorou Saccharomyces Cerevisiae also contains gluthanione, an antioxidant and beta glucan which stimulates the immune system Hong [5]. Of the 15 minerals that it contains, Saccharomyces Cerevisiae consists of chromium a trace mineral which is known as glucose tolerance factor which is essential in the prevention of diabetes, lowers blood pressure and fluctuating blood sugar Zetic [6]. Production of 
proteins from Saccharomyces Cerevisiae (Biomass) is advantageous, because of high protein content and short growth times, leading to rapid biomass production be propagated using cheap raw materials and easily harvested due to their bigger cell sizes and flocculation abilities so it is utilized by biscuits manufacturing companies, as vitamin supplements. It is also used in pharmaceuticals and animal feeds as a source of proteins and vitamin supplements Yamada \& Sgarbieri [7]. This work aims at using increased concentration of Saccharomyces Cerevisiae biomass as live cells to be added to bread dough for the formation of high protein content of bread for promoting good health. This was performed by determining the proximate chemical composition, vitamins, minerals, amino acids profile and sensory evaluation tests of bread.

\section{Material and Method}

\section{Starter cultures}

A commercial mesophilic Saccharomyces Cerevisiae starter culture obtained from (Pakmaya instant yeast, made in Turkey by Pak Gida) was used in bread manufacture as a negative control. One selected strain MY Saccharomyces Cerevisiae from my identified yeasts isolation (my previous work in protein research department- GEBRI/ SRTA- City) was used in four treatments and positive control to improve, increasing protein and amino acids content, fortification and enhances the flavor and texture of bread. MY Saccharomyces Cerevisiae was grown in YPD medium $(10 \mathrm{~g} / \mathrm{L}$ yeast extract; $20 \mathrm{~g} / \mathrm{L}$ peptone; $20 \mathrm{~g} / \mathrm{L}$ glucose) broth at $30-35 \mathrm{oC}$ for 24-48h. then centrifuged on sterilized cups at 3000rpm in $25 \mathrm{oC}$ for $10 \mathrm{~min}$ to remove broth medium, then inoculated overnight in sterilized skim milk at 30 - 35oC, then re-centrifuged to get mediumfreelive cells. The viable count of Saccharomyces Cerevisiae after incubation was 6-8×104 CFU/g by Homothito meter method.

\section{Bread Preparation by Straight-Dough Method}

The straight dough method is the easiest of the dough-making methods where all the ingredients are mixed at the same time in the mixer as described by Ayele [8] with some modification. The bread was reformulated by adding a commercial Saccharomyces Cerevisiae starter culture at $5 \mathrm{~g} / \mathrm{kg}$ wheat flour as a negative control, and selected strain MY Saccharomyces Cerevisiae at 5g/ $\mathrm{kg}$ wheat flour as positive control. Several of MY Saccharomyces Cerevisiae at concentrations of $10 \mathrm{~g} / \mathrm{kg}, 15 \mathrm{~g} / \mathrm{kg}, 20 \mathrm{~g} / \mathrm{kg}$ and $30 \mathrm{~g} /$ $\mathrm{kg}$ wheat flour were prepared. Wheat flour was mixed with salt $(10 \mathrm{~g} / \mathrm{kg})$, sugar $(30 \mathrm{~g} / \mathrm{kg})$, live cell of starter culture Saccharomyces Cerevisiae (divided for negative control, positive control and other treatments) and water to make dough. Proofing of the dough was done at a standard time of $50-60$ minutes at $30-350 \mathrm{C}$ as first fermentation, then divided to five parts for positive control and treatments. More addition of Saccharomyces Cerevisiae live cells at $5,10,15,25 \mathrm{~g} / \mathrm{kg}$ dough were added then putt in stainless pans and left for another 30 minutes as a final proofing step (second fermentation).Treatment and control baked in the electric oven at $250^{\circ} \mathrm{C}$ for $20 \mathrm{~min}$., then cooled for $2 \mathrm{~h}$., baked breads were packed in low-density polyethylene plastic bags and stored for three days at room temperature $\left(24 \pm 2^{\circ} \mathrm{C}\right)$. These dough mixtures and bread samples were evaluated for nutritional value and sensory evaluation.

\section{Quality Attributes Evaluation (Analytical Methods)}

\section{Proximate chemical composition}

\section{a) Moisture content}

The sample (5g) was transferred into a Petri-dish of known weight. The weighed sample was put into an oven at 105 oC until constant weight was obtained AOAC [9]. The difference between the initial and final weight of the sample was recorded as the moisture content.

\section{b) Determination of total carbohydrate}

Determination of total carbohydrate was done using the phenol-sulfuric acid method as described by DuBois [10]. The total concentration of Carbohydrate obtained from bread samples was: Total carbohydrate $(\%)=$ (carbohydrate content from calibration curve/weight of sample) x 100.

\section{c) Determination of crude protein}

Nitrogen content was determined after digestion of about $0.5 \mathrm{~g}$ sample by micro-Kjeldahl method and the ammonia was received in $4 \%$ boric acid according to the method of AOAC [9]. The crude protein (\%) was determined by multiplying the total nitrogen by factor of 6.25 .

\section{d) Determination of fat content}

Crude fat content was determined after extraction of $3.5 \mathrm{~g}$ sample with $50 \mathrm{~mL}$ diethyl ether by Soxhlet extraction method. The solvent was evaporated. The residue was recorded as crude fat content according to AOAC [9].

e) Determination of Energy value: Energy value (kcal per $100 \mathrm{~g}$ ) was estimated using the Atwater conversion factor (Osborne \& Voogt [11].

Energy $($ kcal per 100 g) $=[9 \times$ Lipids $\%+4 \times$ Proteins $\%+4 \times$ Carbohydrates\%].

f) Determination of Vitamin B complex: The vitamin B group was extracted according to a previously described method (AOAC1990) the prepared sample was injected into the HPLC system. Quantification of vitamin B content was accomplished by comparison to vitamin B standards. Standard stock solutions for Thiamine,Riboflavin, Niacin, Pyridoxine, and Cobalamin were prepared as reported previously Aslam [12] and Ringling [13] .Chromatographic separation was achieved on a reversed phase(RP-) HPLC column(Agilent ZORBAX Eclipse Plus C18; $250 \times 4.6 \mathrm{~mm}$ i.d., $5 \mu \mathrm{m}$ ) through the isocratic delivery mobile phase (A/B 33/67; A: $\mathrm{MeOH}, \mathrm{B}: 0.023 \mathrm{M} \mathrm{H3PO4}, \mathrm{pH}=3.54$ ) at a flow rate of $0.5 \mathrm{~mL} /$ min. Ultraviolet (UV) absorbance was recorded at $270 \mathrm{~nm}$ at room temperature Marzougui [14] and Rokayya [15]. 
g) Determination and analysis of Minerals: The mineral contents were assessed by flame atomic absorption spectrophotometer (FAAS - Analytik Jena, Germany) according to AOAC Official Method 985.35 [16] then expressed in fresh weight (mg/100g).

h) Determination of Amino Acids: Amino acids have been extracted from the wheat bread according to Knežević [17]. Each of the defatted samples was weighed (200mg) in to a glass ampoule, $5 \mathrm{ml}$ of $6 \mathrm{~N} \mathrm{HCl} / \mathrm{L}$ was added to the ampoule, and the contents were hydrolyzed in an electric oven preset at $105^{\circ} \mathrm{C}$ for $22 \mathrm{~h}$. Oxygen was expelled in the ampoule by passing nitrogen gas in to it. Amino acid analysis was done by (SYKAM S433 Amino Acids Analyzer). The analysis was carried out with a gas flow rate of $0.5 \mathrm{ml} / \mathrm{min}$ at $60^{\circ} \mathrm{C}$, and the reproducibility was $3 \%$. The amino acid composition was calculated from the areas of standards obtained from the integrator and expressed as percentages of the total protein according to Trajković [18].

i) Sensory Quality Attributes: Sensorial quality was evaluated by a10-panalists, from dept. of food science to score quality attributes of bread. Samples were scored for overall visual quality by using an interval hedonic scale, where the extremes and center of the interval were represented as follows: zero (dislike extremely, no characteristic of the product), 5 (neither like nor dislike, limit of acceptance from the consumer's point of view), and 10 (like extremely, very characteristic of the product). The tested attributes such as texture, taste, odor, color and appearance and overall acceptance were evaluated, according to Eddy [19]. The end of shelf-life was reached when the average value of the samples was judged as unacceptable for consumption by the sensory panel. j) Statistical analysis: All results were presented as means \pm standard deviation (SD). ( $n=3$ ) Values were statistically analyzed by one-way analysis of variance (ANOVA test) according to Steel [20] using SPSS 22 software package. Differences were considered significant at ( $P$ values) less than 0.05 using Duncan Multiple Range test.

\section{Results and Discussion}

\section{Nutrient Analysis}

Table 1 shows the nutrient composition of bread. An increase in nutritional yeast concentration resulted in increase in the protein content of bread. Similar results were reported by Shogran [21] Udofia [22] Noorfarahzilah [23] and Masamba [24].The nutritional yeast used to fortify bread contains high quality protein which was reflected in the fortified bread. Proposed that nutritional yeast is a rich source of protein. Therefore the consumption of nutritional yeast fortified bread means exposure to higher quantity and quality protein Goesaert [25] and Gary [26]). The nutritional yeast fortified bread had a slightly higher content of carbohydrate, moisture and B complex vitamins (Thiamine B1, Riboflavine B2, Niacin B3, Pyridoxamine B6, folic acid B9 and Cyanocobalamin B12) compared to the non-fortified bread sample. These results are in agreement with Ndife [27] and Pareyt [1]. Table 1 revealed also that the fortified bread had higher content of minerals such as (Potassium, Phosphorus, Magnesium, Calcium, Iron and Zinc) compared to the non-fortified bread sample. These results are in agreement with Nwanekezi [28]. It was also noted that lipids and Sodium content were lower in fortified bread because of the addition volume of nutritional yeast. These results are in agreement with (Mashayekh [29] Sanful [30] [Table 1].

Table 1: Means of nutritional value of fortificated bread as influenced by adding three different concentrations of active Saccharomyces Cerevisiae.

\begin{tabular}{|c|c|c|c|c|c|c|}
\hline \multicolumn{2}{|c|}{ Nutritional value } & Control negative & Control positive & Treatment 1 & Treatment 2 & Treatment 3 \\
\hline \multicolumn{2}{|c|}{ Total Calories (Kcal/100g) } & $350.83 \pm 12.03$ & $367.90 \pm 09.50$ & $309.48 \pm 08.32$ & $265.41 \pm 08.11$ & $246.72 \pm 07.21$ \\
\hline \multicolumn{2}{|c|}{ Moisture content \% } & $28.40 \pm 0.17$ & $29.21 \pm 0.199$ & $33.60 \pm 0.26$ & $32.91 \pm 0.25$ & $35.14 \pm 0.193$ \\
\hline \multicolumn{2}{|c|}{ Total Carbohydrate content (g/100g) } & $72.05 \pm 1.46$ & $73.41 \pm 1.52$ & $58.35 \pm 1.38$ & $46.34 \pm 2.10$ & $42.71 \pm 1.59$ \\
\hline \multicolumn{2}{|c|}{ Total protein content (g/100g) } & $8.21 \pm 0.21$ & $10.60 \pm 0.19$ & $12.45 \pm 0.16$ & $13.32 \pm 0.14$ & $13.75 \pm 0.17$ \\
\hline \multicolumn{2}{|c|}{ Total fats content (g/100g) } & $3.31 \pm 0.13$ & $3.54 \pm 0.17$ & $2.92 \pm 0.16$ & $2.53 \pm 0.13$ & $2.32 \pm 0.15$ \\
\hline \multirow{6}{*}{$\begin{array}{c}\text { Total Vitamens } \\
\text { content }\end{array}$} & $\begin{array}{l}\text { Thiamine Vit } \\
\mathrm{B} 1(\mathrm{mg} / 100 \mathrm{~g})\end{array}$ & $18.913 \pm 0.15$ & $21.421 \pm 0.193$ & $25.572 \pm 0.205$ & $26.683 \pm 0.255$ & $30.7125 \pm 0.291$ \\
\hline & $\begin{array}{l}\text { Riboflavine Vit } \\
\text { B2(mg/100g) }\end{array}$ & $0.070 \pm .0002$ & $0.091 \pm 0.0002$ & $0.167 \pm 0.0004$ & $0.3062 \pm 0.0004$ & $0.60575 \pm 0.0001$ \\
\hline & $\begin{array}{c}\text { Niacin Vit } \\
\text { B3(mg/100g) }\end{array}$ & $1.684 \pm 0.104$ & $2.421 \pm 0.108$ & $3.862 \pm 0.11$ & $4.283 \pm 0.104$ & $4.985 \pm 0.11$ \\
\hline & $\begin{array}{l}\text { Pyridoxamine Vit } \\
\text { B6(mg/100g) }\end{array}$ & $0.115 \pm 0.017$ & $0.126 \pm 0.015$ & $0.173 \pm 0.012$ & $0.211 \pm 0.010$ & $0.251 \pm 0.006$ \\
\hline & $\begin{array}{c}\text { folic acid Vit } \\
\text { B9(mg/100g) }\end{array}$ & $0.2113 \pm 0.0004$ & $0.226 \pm 0.0005$ & $0.835 \pm 0.0002$ & $1.0041 \pm .0003$ & $1.5515 \pm 0.0002$ \\
\hline & $\begin{array}{c}\text { Cyanocobalamin } \\
\text { Vit B12(mg/100g) }\end{array}$ & $0.058 \pm 0.01$ & $0.097 \pm 0.005$ & $0.941 \pm 0,006$ & $1.013 \pm 0.005$ & $1.545 \pm 0.003$ \\
\hline
\end{tabular}




\begin{tabular}{|c|c|c|c|c|c|c|}
\hline & $\begin{array}{c}\text { Sodium, Na } \\
\text { (mg/100g) }\end{array}$ & $194.3 \pm 2.53$ & $218.3 \pm 2.25$ & $249.4 \pm 2.41$ & $212.7 \pm 2.18$ & $111.0 \pm 2.21$ \\
\cline { 2 - 6 } & $\begin{array}{c}\text { Potassium, K } \\
\text { (mg/100g) }\end{array}$ & $171.9 \pm 1.69$ & $211.4 \pm 1.95$ & $239.2 \pm 2.13$ & $248.6 \pm 2.23$ & $254.2 \pm 2.18$ \\
\cline { 2 - 7 } $\begin{array}{c}\text { Total Minerals } \\
\text { content }\end{array}$ & $\begin{array}{c}\text { Phosphorus, } \mathrm{P} \\
\text { (mg/100g) }\end{array}$ & $168.7 \pm 2.16$ & $183.2 \pm 2.18$ & $212.5 \pm 2.05$ & $241.2 \pm 3.11$ & $264.1 \pm 2.10$ \\
\cline { 2 - 7 } & $\begin{array}{c}\text { Magnesium, Mg } \\
\text { (mg/100g) }\end{array}$ & $75.12 \pm 1.28$ & $75.13 \pm 1.32$ & $79.47 \pm 1.05$ & $82.51 \pm 1.72$ & $88.42 \pm 1.50$ \\
\cline { 2 - 7 } & $\begin{array}{c}\text { Calcium, Ca } \\
(\mathrm{mg} / 100 \mathrm{~g})\end{array}$ & $26.19 \pm 1.08$ & $27.26 \pm 1.11$ & $34.51 \pm 1.06$ & $37.20 \pm 2.07$ & $40.13 \pm 1.05$ \\
\cline { 2 - 7 } & Iron, Fe (mg/100g) & $2.47 \pm 0.15$ & $2.68 \pm 0.16$ & $4.53 \pm 0.12$ & $5.82 \pm 0.11$ & $6.52 \pm 0.10$ \\
\cline { 2 - 7 } & Zinc, Zn (mg/100g) & $1.77 \pm 0.09$ & $1.83 \pm 0.07$ & $2.21 \pm 0.09$ & $2.53 \pm 0.11$ & $2.75 \pm 0.08$ \\
\hline
\end{tabular}

Values are means of three determinations \pm standard deviation $(n=3)$. Values in the same row are not statistically different $(p<0.05)$. $($ Negative Control $)=$ Reformulated by adding a commercial Saccharomyces Cerevisiae starter culture in the range $5 \mathrm{~g} / \mathrm{kg}$ wheat flour (Positive Control) $=$ Reformulated by adding selected isolated strain MY Saccharomyces Cerevisiae in the range $5 \mathrm{~g} / \mathrm{kg}$ wheat flour (Treatment 1) = Reformulated by adding selected isolated strain MY Saccharomyces Cerevisiae in the range $10 \mathrm{~g} / \mathrm{kg}$ wheat flour (Treatment 1) = Reformulated by adding selected isolated strain MY Saccharomyces Cerevisiae in the range $10 \mathrm{~g} / \mathrm{kg}$ wheat flour (Treatment 3) = Reformulated by adding selected isolated strain MY Saccharomyces Cerevisiae in the range $20 \mathrm{~g} / \mathrm{kg}$ wheat flour

\section{Sensory Evaluation}

Color and Appearance of Bread: Vaclavik and Christian [31] described appearance of food as the size, color, structure, transparency of turbidity and degree of wholeness or damage of the product. Structure and color are important in baked goods for example bread should have white and brown color and should have many holes uniformly spread throughout otherwise a slight drift from normal will be judged as a quality defect. Table 2 shows people responses to the appearances of bread samples. All the bread samples were baked using white flour and the change in color was a result of incorporation of different nutritional yeast concentrations. The darker color noticed in bread samples with higher concentrations of nutritional yeast was a result of enhanced Maillard reactions Mottram [32] between reducing sugars and proteins. Most people preferred the appearance of bread sample T1 since it resembled the color of brown bread available on commercial market. This shows that many consumers prefer brown bread to white bread when considering color only. Sample T3was regarded as unacceptable by the respondents due to its dark brown color which they perceived as unattractive.

Taste of Bread: Taste was the main attribute in rating of the samples since addition of the nutritional yeast had an effect of changing the taste of the bread. Tepper and Ulrich [33] defined taste as a combination of five major tastes: salty; sweet; sour; bitterand umami. Taste is detected by taste buds at the tips, sides and back of the tongue and the sensitivity to a particular taste depends on the concentration of the substance responsible for the taste. The responses to the taste of different bread samples are shown in Table 2 the respondents liked the taste of sample T1 most largely because it had the taste of what they already perceive as normal and fresh bread taste. Samples T2 and T3 had lows cores due to the cheese like taste of the nutritional yeast which was appealing to most respondents who originally prefer cheese. Bread sampleT4 was regarded as unacceptable for human consumption as a result of a bitter after taste experienced by the consumers.

Table 2: Means of sensory score values of bread as influenced by adding four different concentrations of active yeast.

\begin{tabular}{|c|c|c|c|c|c|}
\hline Treatments & Sensory test & $\begin{array}{c}\text { Mean of score values } \\
\text { befor beaking }\end{array}$ & $\begin{array}{c}\text { Mean of score values } \\
\text { after } \mathbf{h} \text { h. of beaking }\end{array}$ & $\begin{array}{c}\text { Mean of score values } \\
\text { after one day of } \\
\text { beaking }\end{array}$ & $\begin{array}{c}\text { Mean of score values } \\
\text { after three days of } \\
\text { beaking }\end{array}$ \\
\hline Control negative & Taste & $\mathrm{nd}^{*}$ & $8.49 \pm 1.21$ & $7.14 \pm 1.13$ & $4.16 \pm 1.04$ \\
\hline & colour and appearance & $9.12 \pm 1.06$ & $9.32 \pm 1.06$ & $9.23 \pm 2.04$ & $8.65 \pm 1.31$ \\
\hline & Texture & $9.01 \pm 1.10$ & $9.14 \pm 1.07$ & $6.11 \pm 1.62$ & $4.27 \pm 1.51$ \\
\hline & odour & $9.13 \pm 1.12$ & $8.61 \pm 1.12$ & $8.05 \pm 1.36$ & $7.63 \pm 1.12$ \\
\hline & over all acceptance & $9.15 \pm 1.37$ & $9.12 \pm 2.11$ & $6.73 \pm 1.61$ & $5.12 \pm 1.73$ \\
\hline Control positive & Taste & nd & $9.38 \pm 1.13$ & $7.48 \pm 1.13$ & $5.87 \pm 1.31$ \\
\hline & colour and appearance & $9.41 \pm 1.13$ & $9.64 \pm 1.41$ & $9.55 \pm 2.11$ & $8.92 \pm 1.21$ \\
\hline & Texture & $9.24 \pm 1.27$ & $9.67 \pm 1.21$ & $6.43 \pm 1.02$ & $5.39 \pm 1.14$ \\
\hline & odour & $9.57 \pm 1.05$ & $9.37 \pm 1.34$ & $8.65 \pm 1.13$ & $8.33 \pm 1.27$ \\
\hline
\end{tabular}




\begin{tabular}{|c|c|c|c|c|c|}
\hline & over all acceptance & $9.88 \pm 2.05$ & $9.55 \pm 2.06$ & $7.32 \pm 1.51$ & $5.74 \pm 1.83$ \\
\hline \multirow[t]{5}{*}{ Treatment 1} & Taste & nd & $8.75 \pm 1.08$ & $8.52 \pm 1.31$ & $7.82 \pm 1.04$ \\
\hline & color and appearance & $7.34 \pm 1.41$ & $9.12 \pm 1.21$ & $8.85 \pm 1.26$ & $8.13 \pm 1.31$ \\
\hline & Texture & $7.53 \pm 1.07$ & $9.13 \pm 1.32$ & $7.76 \pm 1.24$ & $6.43 \pm 1.06$ \\
\hline & odour & $8.65 \pm 1.23$ & $8.97 \pm 1.62$ & $8.21 \pm 1.08$ & $7.83 \pm 1.53$ \\
\hline & over all acceptance & $8.23 \pm 2.17$ & $8.63 \pm 2.13$ & $7.83 \pm 1.68$ & $7.36 \pm 1.78$ \\
\hline \multirow[t]{5}{*}{ Treatment 2} & Taste & nd & $7.58 \pm 1.14$ & $7.31 \pm 1.21$ & $6.63 \pm 1.31$ \\
\hline & colour and appearance & $6.93 \pm 1.08$ & $8.64 \pm 1.31$ & $7.92 \pm 1.32$ & $7.73 \pm 1.46$ \\
\hline & Texture & $6.22 \pm 1.73$ & $8.86 \pm 1.12$ & $8.11 \pm 1.53$ & $7.33 \pm 1.61$ \\
\hline & odour & $8.49 \pm 1.24$ & $8.31 \pm 1.27$ & $7.65 \pm 1.12$ & $7.11 \pm 2.18$ \\
\hline & over all acceptance & $7.65 \pm 1.85$ & $8.21 \pm 2.05$ & $7.34 \pm 1.74$ & $6.93 \pm 1.73$ \\
\hline \multirow[t]{5}{*}{ Treatment 3} & Taste & nd & $6.24 \pm 1.03$ & $6.45 \pm 1.14$ & $5.93 \pm 1.05$ \\
\hline & colour and appearance & $6.45 \pm 1.06$ & $6.45 \pm 1.12$ & $6.12 \pm 1.25$ & $5.73 \pm 1.13$ \\
\hline & Texture & $5.82 \pm 1.01$ & $8.65 \pm 1.02$ & $7.9 \pm 1.34$ & $7.31 \pm 1.64$ \\
\hline & odour & $7.52 \pm 1.05$ & $7.55 \pm 1.04$ & $6.31 \pm 1.15$ & $5.84 \pm 1.21$ \\
\hline & over all acceptance & $6.74 \pm 1.58$ & $7.23 \pm 1.63$ & $6.55 \pm 1.47$ & $5.97 \pm 1.93$ \\
\hline \multirow[t]{5}{*}{ Treatment 4} & Taste & nd & $4.23 \pm 1.05$ & nd & nd \\
\hline & colour and appearance & $6.12 \pm 1.11$ & $3.55 \pm 0.93$ & nd & nd \\
\hline & Texture & $4.28 \pm 1.04$ & $4.25 \pm 1.07$ & nd & nd \\
\hline & odour & $3.12 \pm 0.54$ & $4.11 \pm 1.12$ & nd & nd \\
\hline & over all acceptance & $4.52 \pm 1.47$ & $4.05 \pm 1.54$ & nd & nd \\
\hline
\end{tabular}

Values are means of three determinations \pm standard deviation $(n=3)$. Values in the same row are not statistically different $(p<0.05)$.

(Negative Control) $=$ Reformulated by adding a commercial Saccharomyces Cerevisiae starter culture in the range $5 \mathrm{~g} / \mathrm{kg}$ wheat flour

(Positive Control) $=$ Reformulated by adding selected isolated strain MY Saccharomyces Cerevisiae in the range $5 \mathrm{~g} / \mathrm{kg}$ wheat flour

(Treatment 1) = Reformulated by adding selected isolated strain MY Saccharomyces Cerevisiae in the range $10 \mathrm{~g} / \mathrm{kg}$ wheat flour

(Treatment 2) = Reformulated by adding selected isolated strain MY Saccharomyces Cerevisiae in the range $15 \mathrm{~g} / \mathrm{kg}$ wheat flour

(Treatment 3) = Reformulated by adding selected isolated strain MY Saccharomyces Cerevisiae in the range $20 \mathrm{~g} / \mathrm{kg}$ wheat flour

(Treatment 4) = Reformulated by adding selected isolated strain MY Saccharomyces Cerevisiae in the range $30 \mathrm{~g} / \mathrm{kg}$ wheat flour

Flavor of Bread: Flavor is one of the major sensory properties which are decisive in acceptance and selection. Vaclavik and Christian [31] defined flavor as a combination of smell and taste which is largely subjective. Table 2 shows consumer responses to bread flavor of different nutritional yeast concentration. As the level of nutritional yeast increased, the typical flavor associated with bread decreased. There spondents accepted flavor of bread samples T1, T2 and T3 but rejected bread samples T4 as a result of strong yeast smell. Consumers are more likely to accept products that they are familiar with. Any deviation in flavor is deemed as quality defect.

Bread Texture: Texture refers to those qualities of food that can be felt with fingers, tongue, palate or teeth Murano [34]. The texture of bread samples is shown in Table 2. The respondents found the texture of samples T1, T2 and T3 as highly acceptable. Sample T4was regarded as unacceptable in terms of texture due to the high amounts of moisture in the bread samples which resulted in a lumpy crumb structure instead of an open texture.
Amino acids Analysis: The results of Table 3 the qualitative analysis showed the variability in the amino acid composition in the examined wheat genotype. For all analyzed cultivars have been identified 18 different amino acids. These results suggest that wheat flour and non-fortified bread protein is deficient in certain essential amino acids, such as lysine, tryptophan, threonine, methionine and histidine. Wheat protein is rich in glutamic acid and proline, which are the dominating non- essential amino acids. Paterson [35] also reported the deficiency of lysine, tryptophan and methionine in wheat protein; likewise Khan [36] reported that lysine is the limiting essential amino acid in wheat grain protein. In contrast fortified bread treatments showed highly increase in certain essential and non- essential amino acids. At the same time it should be noted that the lysine has been higher increase value in fortified bread treatments which is in agreement with the experience of Yalçın [37] who used a similar technique with fortified bread. According to the results of the analysis the most present amino acids in the examined wheat flour were glutamic 
acid, glycine, sarcosine, valine, norvaline and tryptophan. It is well known, that glutamic acid and glycine are principal amino acids in all cereal protein fractions. Likewise Sejian [38] and Knezevic [39] found that increase in the protein content of wheat grain showed differences among wheat genotypes. Considering that amino acid composition of wheat flour proteins is genetically determined, it Table 3: Means of Amino acids concentration value of wheat flour and fortificated wheat bread as influenced by adding three different concentrations of active Saccharomyces Cerevisiae as (mg/gm).

\begin{tabular}{|c|c|c|c|c|c|c|c|c|c|c|}
\hline No. & Amino Acids & & $\begin{array}{c}\text { commercial } \\
\text { Saccharomyces } \\
\text { Cerevisiae } \\
\text { starter } \\
\text { culture }\end{array}$ & $\begin{array}{c}\text { selected } \\
\text { isolated } \\
\text { strain MY } \\
\text { Saccharomyces } \\
\text { Cerevisiae }\end{array}$ & $\begin{array}{l}\text { Wheat flour } \\
\text { glutein }\end{array}$ & $\begin{array}{c}\text { control } \\
\text { negative }\end{array}$ & $\begin{array}{l}\text { control } \\
\text { positive }\end{array}$ & $\begin{array}{c}\text { treatment } \\
1\end{array}$ & treatment 2 & $\begin{array}{c}\text { treatment } \\
3\end{array}$ \\
\hline \multicolumn{11}{|c|}{ Essential amino acids } \\
\hline 1 & Threonine & Thr & $25.4 \pm 1.3$ & $31.8 \pm 1.2$ & $0.0122 \pm 0.001$ & $\begin{array}{l}0.0061 \pm \\
0.003\end{array}$ & $\begin{array}{c}0.0563 \pm \\
0.004\end{array}$ & $\begin{array}{c}0.4553 \pm \\
0.021\end{array}$ & $0.6725 \pm 0.09$ & $\begin{array}{l}0.8436 \pm \\
0.2\end{array}$ \\
\hline 2 & Valin & Val & $15.1 \pm 0.6$ & $13.4 \pm 0.5$ & $\begin{array}{c}0.0975 \pm \\
0.006\end{array}$ & $\begin{array}{l}0.0412 \pm \\
0.005\end{array}$ & $\begin{array}{c}0.4213 \pm \\
0.01\end{array}$ & $\begin{array}{c}1.0049 \pm \\
0.06\end{array}$ & $1.385 \pm 1.01$ & $\begin{array}{c}1.5186 \pm \\
1.05\end{array}$ \\
\hline 3 & Methionine & Met & $7.41 \pm 0.6$ & $8.5 \pm 0.3$ & $0.1109 \pm 0.05$ & $\begin{array}{l}0.008 \pm \\
0.002\end{array}$ & $\begin{array}{c}0.0036 \pm \\
0.001\end{array}$ & $\begin{array}{c}0.0724 \pm \\
0.01\end{array}$ & $0.186 \pm 0.03$ & $\begin{array}{c}0.33 \pm \\
0.01\end{array}$ \\
\hline 4 & Isoleucine & Ile & $14.32 \pm 0.3$ & $16.5 \pm 0.6$ & $1.048 \pm 0.07$ & $\begin{array}{l}0.122 \pm \\
0.03\end{array}$ & $\begin{array}{c}0.241 \pm \\
0.006\end{array}$ & $\begin{array}{c}0.902 \pm \\
0.004 \\
\end{array}$ & $1.053 \pm 0.08$ & $\begin{array}{c}1.8018 \pm \\
0.12\end{array}$ \\
\hline 5 & Leucine & Leu & $21.9 \pm 1.0$ & $25.6 \pm 1.1$ & $1.7312 \pm 0.15$ & $\begin{array}{l}0.553 \pm \\
0.03\end{array}$ & $\begin{array}{c}0.731 \pm \\
0.07\end{array}$ & $\begin{array}{c}1.628 \pm \\
0.18\end{array}$ & $2.143 \pm 0.13$ & $\begin{array}{c}3.321 \pm \\
0.16\end{array}$ \\
\hline 6 & Phenylalanine & Phe & $30.5 \pm 2.1$ & $33.6 \pm 3.4$ & $1.0521 \pm 0.12$ & $\begin{array}{l}0.398 \pm \\
0.05\end{array}$ & $\begin{array}{c}0.632 \pm \\
0.008\end{array}$ & $\begin{array}{c}1.2056 \pm \\
0.11\end{array}$ & $\begin{array}{c}1.9878 \pm \\
0.81\end{array}$ & $\begin{array}{c}2.1432 \pm \\
0.69\end{array}$ \\
\hline 7 & Histidine & His & $8.61 \pm 1.2$ & $9.6 \pm 1.8$ & $0.421 \pm 0.03$ & $\begin{array}{c}0.251 \pm \\
0.01\end{array}$ & $\begin{array}{c}0.103 \pm \\
0.05\end{array}$ & $\begin{array}{l}0.529 \pm \\
0.04\end{array}$ & $\begin{array}{c}0.8332 \pm \\
0.08\end{array}$ & $\begin{array}{l}0.9422 \pm \\
0.03\end{array}$ \\
\hline 8 & Lysine & lys & $34.7 \pm 2.4$ & $33.6 \pm 3.4$ & $0.008 \pm 0.01$ & $\begin{array}{c}0.199 \pm \\
0.04\end{array}$ & $\begin{array}{l}0.215 \pm \\
0.002 \\
\end{array}$ & $\begin{array}{c}0.724 \pm \\
0.011 \\
\end{array}$ & $\begin{array}{l}0.9763 \pm \\
0.052\end{array}$ & $\begin{array}{c}1.0176 \pm \\
0.083\end{array}$ \\
\hline 9 & Tryptophan & Trp & $3.11 \pm 0.8$ & $2.8 \pm 0.6$ & $0.113 \pm 0.005$ & $\begin{array}{c}0.0629 \pm \\
0.006\end{array}$ & $\begin{array}{c}0.104 \pm \\
0.011\end{array}$ & $\begin{array}{c}0.3501 \pm \\
0.019\end{array}$ & $\begin{array}{c}0.5201 \pm \\
0.038\end{array}$ & $\begin{array}{l}0.631 \pm \\
0.075\end{array}$ \\
\hline \multicolumn{11}{|c|}{ Nonessential amino acids } \\
\hline 10 & Aspartic acid & Asp & $25.9 \pm 1.4$ & $28.2 \pm 1.7$ & $0.131 \pm 0.01$ & $\begin{array}{l}0.499 \pm \\
0.012\end{array}$ & $\begin{array}{l}0.763 \pm \\
0.035\end{array}$ & $\begin{array}{c}1.335 \pm \\
0.91\end{array}$ & $\begin{array}{c}1.9043 \pm \\
0.59\end{array}$ & $\begin{array}{l}2.1026 \pm \\
0.78\end{array}$ \\
\hline 11 & Serine & Ser & $33.2 \pm 1.7$ & $38.9 \pm 1.4$ & $\begin{array}{c}0.0831 \pm \\
0.006\end{array}$ & $\begin{array}{c}0.0453 \pm \\
0.003\end{array}$ & $\begin{array}{c}0.07742 \pm \\
0.006\end{array}$ & $\begin{array}{c}0.2037 \pm \\
0.052\end{array}$ & $\begin{array}{c}0.4221 \pm \\
0.031\end{array}$ & $\begin{array}{c}0.5468 \pm \\
0.03\end{array}$ \\
\hline 12 & Glutamic acid & Glu & $30.2 \pm 1.6$ & $33.0 \pm 2.0$ & $1.2109 \pm 0.42$ & $\begin{array}{l}4.233 \pm \\
1.04\end{array}$ & $\begin{array}{l}3.841 \pm \\
1.52\end{array}$ & $\begin{array}{l}9.793 \pm \\
1.92\end{array}$ & $\begin{array}{c}13.164 \pm \\
2.17\end{array}$ & $\begin{array}{c}15.1828 \pm \\
2.56\end{array}$ \\
\hline 13 & Prolin & Pro & $8.11 \pm 0.4$ & $8.6 \pm 0.8$ & $1.048 \pm 0.021$ & $\begin{array}{c}1.209 \pm \\
0.38\end{array}$ & $\begin{array}{l}0.945 \pm \\
0.036\end{array}$ & $\begin{array}{c}2.033 \pm \\
0.89\end{array}$ & $2.997 \pm 1.05$ & $\begin{array}{c}4.2394 \pm \\
1.83\end{array}$ \\
\hline 14 & Glycine & Gly & $0.011 \pm 0.06$ & $0.007 \pm 0.02$ & $0.112 \pm 0.05$ & $\begin{array}{l}0.15 \pm \\
0.012\end{array}$ & $\begin{array}{c}0.0524 \pm \\
0.005\end{array}$ & $\begin{array}{l}0.367 \pm \\
0.054\end{array}$ & $0.522 \pm 0.03$ & $\begin{array}{l}0.711 \pm \\
0.004\end{array}$ \\
\hline 15 & Alanine & Ala & $8.91 \pm 0.02$ & $8.4 \pm 0.06$ & $\begin{array}{c}0.0825 \pm \\
0.011\end{array}$ & $\begin{array}{c}0.692 \pm \\
0.031\end{array}$ & $\begin{array}{c}0.8353 \pm \\
0.046\end{array}$ & $\begin{array}{l}1.783 \pm \\
0.93\end{array}$ & $\begin{array}{c}2.1033 \pm \\
0.94\end{array}$ & $\begin{array}{c}2.3496 \pm \\
0.89\end{array}$ \\
\hline 16 & Tyrosine & Tyr & $0.66 \pm 0.5$ & $0.9 \pm 0.1$ & $\begin{array}{c}0.0517 \pm \\
0.004\end{array}$ & $\begin{array}{c}0.0118 \pm \\
0.0027\end{array}$ & $\begin{array}{c}0.00345 \pm \\
0.0007\end{array}$ & $\begin{array}{c}0.2749 \pm \\
0.03\end{array}$ & $\begin{array}{c}0.4839 \pm \\
0.007\end{array}$ & $\begin{array}{c}0.5152 \pm \\
0.006\end{array}$ \\
\hline 17 & Cysteine & Cys & $0.82 \pm 0.13$ & $0.528 \pm 0.11$ & $1.494 \pm 0.032$ & $\begin{array}{c}1.931 \pm \\
0.71\end{array}$ & $\begin{array}{c}1.037 \pm \\
0.84\end{array}$ & $\begin{array}{c}3.628 \pm \\
1.07\end{array}$ & $4.827 \pm 1.24$ & $\begin{array}{c}5.905 \pm \\
1.72\end{array}$ \\
\hline 18 & Arginine & Arg & $16.3 \pm 1.1$ & $13.8 \pm 1.6$ & $\begin{array}{c}0.4933 \pm \\
0.006\end{array}$ & $\begin{array}{l}0.623 \pm \\
0.0051\end{array}$ & $\begin{array}{c}0.435 \pm \\
0.06\end{array}$ & $\begin{array}{c}0.9531 \pm \\
0.05\end{array}$ & $1.225 \pm 0.69$ & $\begin{array}{c}1.5438 \pm \\
0.74\end{array}$ \\
\hline
\end{tabular}

Values are means of three determinations \pm standard deviation $(n=3)$. Values in the same row are not statistically different $(p<0.05)$.

$($ Negative Control $)=$ Reformulated by adding a commercial Saccharomyces Cerevisiae starter culture in the range $5 \mathrm{~g} / \mathrm{kg}$ wheat flour (Postive Control) $=$ Reformulated by adding selected isoleted strain MY Saccharomyces Cerevisiae in the range $5 \mathrm{~g} / \mathrm{kg}$ wheat flour 
(Treatment 1$)=$ Reformulated by adding selected isoleted strain MY Saccharomyces Cerevisiae in the range $10 \mathrm{~g} / \mathrm{kg}$ wheat flour (Treatment 2) = Reformulated by adding selected isoleted strain MY Saccharomyces Cerevisiae in the range $15 \mathrm{~g} / \mathrm{kg}$ wheat flour (Treatment 3) = Reformulated by adding selected isoleted strain MY Saccharomyces Cerevisiae in the range $20 \mathrm{~g} / \mathrm{kg}$ wheat flour

\section{Conclusion}

The protein content spatially essential amino acids content of the homemade bread was improved through nutritional yeast fortification. The carbohydrate, B complex vitamins and minerals content of the fortified bread were improved. The flavor and taste greatly influenced consumer acceptance of the product. Addition of artificial flavorings to mask the strong flavor of the nutritional yeast could help improve the taste and consumer acceptability of the fortified bread [42,43]. For increasing of amino acid content as well composition of free essential amino acids in grain of wheat we need to increase our knowledge about mechanisms of the control grain protein accumulation at the molecular, biochemical and physiological levels. Also, for improving nutritional value are necessary to select wheat genotypes in terms of essential amino acids content and higher protein content.

\section{References}

1. Pareyt B, Finnie SM, Putseys JA, Delcour JA (2011) Lipids in bread making: Sources, interactions, and impact on bread quality. Journal of Cereal Science 54(3): 266-279.

2. Wardlaw MG, Hamphl SJ, Disilvestro AR (2004) Perspectives in nutrition. New York McGraw-Hill.

3. Friedman M, Finot PA (1990) Nutritional improvement of bread with lysine and gamma-glutamyllysine. Journal of Agricultural and Food Chemistry 38(11): 2011-2020.

4. Shrinandan B (2010) Food and nutrition. I.T.B.S Publishers, India.

5. Hong L, Xun M, Wutong W (2007) Anti-diabetic effect of an A-glucan from fruit body of Maitake (Grifola Frondosa) on KK-Ay mice. J Pharm Pharmacol 59(4): 575-582.

6. Zetic VG, Stehlik-Tomas V, Grba S, Lutilsky L (2001) Chromium uptake by Saccharomyces Cerevisiae and isolation of glucose tolerance factor from yeast biomass. J Biosci 26(2): 217-223.

7. Yamada EA, Sgarbieri VC, (2005) Yeast (Saccharomyces Cerevisiae) protein concentrate: preparation, chemical composition, and nutritional and functional properties. Journal of Agricultural and Food Chemistry 53(10): 3931-3936.

8. Ayele Haimanot $\mathrm{H}$, Geremew Bultosa, Tilahun Abera, Tessema Astatkie (2017) Nutritional and sensory quality of wheat bread supplemented with cassava and soybean flours. Journal of Cogent Food \& Agriculture.

9. AOAC (2006) Official methods of analysis of AOAC International $\left(18^{\text {th }}\right.$ edn.), Gaithersburg: Association of Analytical Communities.

10. DuBois M, KA Gilles, JK Hamilton, PA Rebers, Fred Smith (1956) Colorimetric method for determination of sugars and related substances. Analytical Chemistry 28(3): 350- 356.

11. Osborne DR, Voogt P (1978) The Analysis of Nutrients in Foods "Food Science and Technology", A Series of monographs illustrated. Academic Press, USA pp.251.

12. Aslam J, Mohajir MS, Khan SA, Khan AQ (2008) HPLC analysis of watersoluble vitamins (B1, B2, B3, B5, B6) in in vitro and ex vitro germinated chickpea (Cicer arietinum L.). African Journal of Biotechnology 7(14): 2310-2314

13. Ringling C, Rychlik M (2013) Analysis of seven folates in food by LC-MS/ MS to improve accuracy of total folate data. European Food Research and Technology 236(1): 17-28.

14. Marzougui N, Guasmi F, Mkaddem M (2009) Assessment of Tunisian Trigonella foenum graecum diversity using seed vitamin B6, B1, B9 and C contents. Journal of Food Agriculture and Environment 7(1): 56-61.

15. Rokayya Sami, Yang Li, Baokun Qi, Shengnan Wang, Qiaozhi Zhang, et al. (2014) HPLC Analysis of Water-Soluble Vitamins (B2, B3, B6, B12, and $\mathrm{C}$ ) and Fat-Soluble Vitamins (E, K, D, A, and $\beta$-Carotene) of Okra (Abelmoschus esculentus). Journal of Chemistry Volume 2014: 6.

16. AOAC (1990) Official methods of analysis of AOAC International $\left(15^{\text {th }}\right.$ edn.), Gaithersburg: Association of Analytical Communities.

17. Knežević SD, Djukić N, Paunović A, Madić M (2009) Amino acid content in grains of different winter wheat (Triticum aestivum L.) varieties. Cereal Research Communications 37: 647-650.

18. Trajković J, Mirić M, Baras J, Šiler S (1983) Analysis of food products. University of Belgrade.

19. Eddy NO, Udofia PG, Eyo D (2007) Sensory evaluation of wheat/cassava composite bread and effect of label information on acceptance and preference. African Journal of Biotechnology 6(20): 2415-2418.

20. Steel R, Torrie J, Dickey D (1997) Principles and Procedures of Statistics: A Biometrical Approach. ( $3^{\text {rd }}$ edn.), McGraw-Hill, New York, USA.

21. Shogren RL, Mohamed AA, Carriere CJ (2003) Sensory Analysis of whole wheat/soy flour breads. Journal of Food Science 68(6): 2141-2145.

22. Udofia PG, Udoudo PJ, Eyen NO (2013) Sensory evaluation of wheatcassava- soybean composite flour (WCS) bread by the mixture experiment design. African Journal of Food Science 7(10): 368-374.

23. Noorfarahzilah M, Lee JS, Sharifudin MS, Fadzelly MAB, Hasmadi M (2014) Applications of composite flour in development of food products. International Food Research Journal 21(6): 2061-2074.

24. Masamba K, Jinazali H (2014) Effect of cassava flour processing methods and substitution level on proximate composition, sensory characteristics and overall acceptability of bread made from wheat-cassava flour blends. African Journal of Food Agriculture Nutrition and Development 14(6): 2190-2203.

25. Goesaert H, Brijs K, Veraverbeke WS, Courtin CM, Gebruers K, Delcour JA (2005) Wheat flour constituents: How they impact bread quality, and how to impact their functionality. Trends in Food Science and Technology 16(1-3): 12-30.

26. Garg S, Lule VK, Malik RK, Tomar SK (2016) Soy Bioactive components in functional perspective: A review. International Journal of Food Properties 19: 2550-2574.

27. Ndife J, Abdulraheem LO, Zakari UM (2011) Evaluation of the nutritional and sensory quality of functional breads produced from whole wheat and soya bean flour blends. African Journal of Food Science 5(8): 466472 .

28. Nwanekezi EC (2013) Composite flours for baked products and possible challenges-A review. Nigerian Food Journal 31(2): 8-17.

29. Mashayekh M, Mahmoodi MR, Entezari MH (2008) Effect of fortification of defatted soy flour on sensory and rheological properties of wheat 
bread. International Journal of Food Science and Technology 43(9): 1693-1698.

30. Sanful RE, Darko S (2010) Utilization of soybean flour in the production of bread. Pakistan Journal of Nutrition 9(8): 15-818.

31. Vaclavik VA, Christian WE (2008) Essentials in food science. Springer New York, USA.

32. Mottram DS, Wedzicha BL, Dodson AT (2002) Food chemistry: acrylamide is formed in the Maillard reaction. Nature 419(6906): 448449.

33. Tepper BJ, Ulrich U (2002) Taste, smell and the genetics of food preferences. SAGE Publications, London.

34. Murano PS (2003) Understanding food science and technology. Peter Marshall Publishers, New York, USA.

35. Patterson DT, Flint EP (1990) Implications of increasing carbon dioxide and climate change for plant communities and competition in natural and managed ecosystems. Impact of carbon dioxide, trace gases, and climate change on global agriculture (impact of carbon) p. 83-110.

36. Khan Muhammad Saleem, Ali Ehsan, Ali Sajjad , Khan Wisal Muhammad , Sajjad Muhammad Anwar, et al. (2014) Assessment of essential amino acids in wheat proteins: a case study. Journal of Biodiversity and Environmental Sciences 4(6): 185-189.
37. Yalçın Sakine, Yalçın Suzan, Pınar Can, Arif O Gürdal, CemalettinBağcl, et al. (2011) The Nutritive Value of Live Yeast Culture (Saccharomyces cerevisiae) and Its Effect on Milk Yield, Milk Composition and Some Blood Parameters of Dairy Cows. Asian-Aust J Anim Sci 24(10): 13771385.

38. Sejian V, Srivastava RS (2010) Effects of melatonin on adrenal cortical functions of Indian goats under thermal stress. Veterinary medicine international.

39. Knežević Desimir, Mihajlović Dijana, Kondić Danijela (2013) Contents of Amino Acids in Grains of Different Bread Wheat Genotypes. Journal of Agriculture knowledge 14(3): 431-439.

40. Ahmad I, Hussain T, Hamidullah Shah (1986) Department of Agricultural Chemistry and Nutrition, NWFP Agricultural University, Peshawar. Pakistan Journal of Biochemistry 19(1-2): 13.

41. Jensen RA (1976) Enzyme recruitment in evolution of new function. Annu Rev Microbiol 30(1): 409-425.

42. Bradstreet RB (1965) The Kjeldahl method for organic nitrogen. New York Academic Press.

43. Gomez KA, Gomez AA (1984) Statistical procedures for Agriculutural Research ( $2^{\text {nd }}$ edn.), An International Rice Research Institute Book. A Wiley Intersciencee publisher, New York, USA.

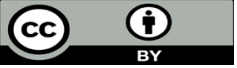

This work is licensed under Creative Commons Attribution 4.0 License

Submission Link:

$$
\text { Submit Article }
$$

DOI: $10.32474 /$ CDVS.2018.01.000109

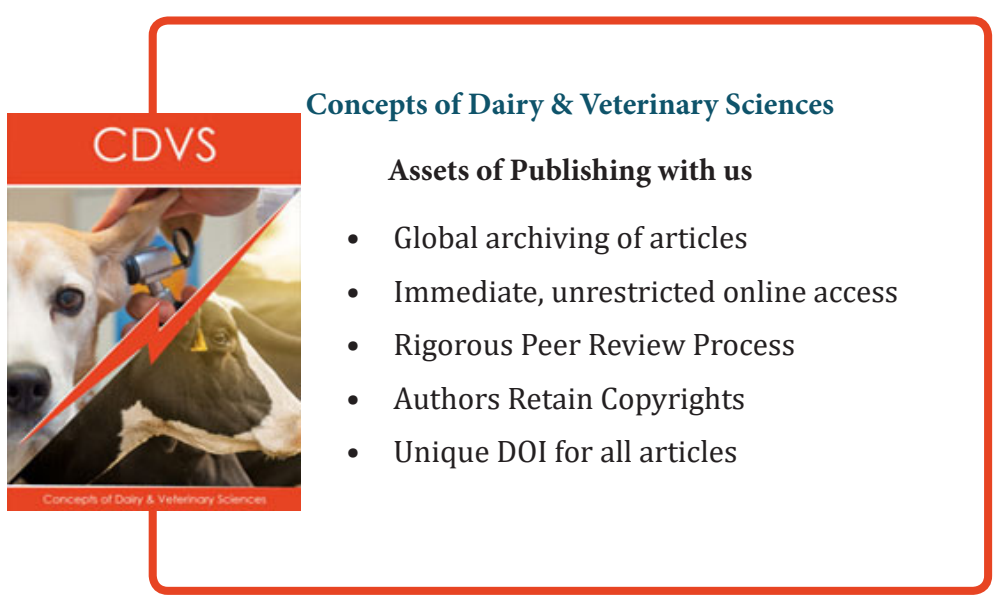

